7. Goran B, Tomislav T, Ivanka S, Miodrag S, Vuka K, Marica O, Gordana B. Biochemical, cytological and microbiological characteristics of the cirrhotic, malignant and mixed ascites. J Oncol. 2001; 9: 95-101.

8. Sharatchandra LK, Mingsen T, Singh YI, Narendra RK, Ranjan S, Singh WG. SALG in alcoholic cirrhosis, tuberculosis and malignancy. JIACM. 2005; 6: 306-11.

9. Bijoor AR, Venkatesh $\mathrm{T}$. Value of ascitic fluid cholesterol and serum-ascites albumin gradient in differentiating cirrhotic and malignancy related ascites. Indian J Clin Biochem. 2001; 6: 106-09.

10. Lu CW, Wang SS, Lee SD, Tsai YT, Lee FY, Shiesh SC, Wu SL, Lu RH, Lo KJ. Ascitic fluid analysis in peritoneal carcinomatosis: Comparison of various biochemical tests with ascitic cirrhotics. Chin Med J. 1991; 47: 350-56.

\section{Comparative study of efficacy of brush cytology and transthoracic fine needle aspiration cytology in the diagnosis of bronchogenic carcinoma}

For long time, bronchoscopic biopsy for histopathology remains the standard in the diagnosis of bronchogenic carcinoma ${ }^{1-3}$. The diagnostic yield from biopsy of bronchoscopically visible tumors, occupying the lumen of bronchus is over $90 \%{ }^{3}$. The yield from the bronchoscopically visible but deep seated or intramural tumor is $50-60 \%{ }^{3}$. In cases of peripheral tumors, the diagnostic yield is much lower. The process usually fails in small peripheral lesions, in the lesions where the bronchi become fibrosed or narrowed, so that the bronchoscope could not reach the site of the lesion ${ }^{3}$. Bronchial cytobrushing, an ancilliary process done during bronchoscopy, yields better results. Bronchial cytobrushing could be done from area of suspicion, having chance of uncertain biopsy ${ }^{3}$. By examination of the bronchial brush specimen, it is now possible to make a diagnosis in $80-90 \%$ of patients with lung carcinoma ${ }^{4}$. Transthoracic fine needle aspiration cytology (FNAC) is another pulmonary diagnostic procedure, widely practiced throughout the world. It is a safe, speedy and effective method in the diagnosis of bronchogenic carcinoma. It can be performed on out-patient basis, requiring no or only local anesthesia. It has wide patient acceptance as it is less traumatic and minimally invasive ${ }^{5}$. It can be done anywhere in the thorax under image guidance, especially under CT-guidance ${ }^{6}$.

The aim of this study was to find out the efficacy of transthoracic fine needle aspiration cytology and brush in the diagnosis of bronchogenic carcinoma and to compare cytopathological finding of transthoracic FNA and brush cytology with histopathological findings of bronchoscopic specimen and to assess the reliability of 2 cytological techniques.

Seventy (58 males; 12 females; mean age 60.2 years) clinically suspected patients of bronchogenic carcinoma were selected. Patients having any clinical feature suspicious of lung cancer with nonresoluting shadow in the chest $\mathrm{x}$-ray in spite of proper antibiotic treatment, were included.

Transthoracic FNA were done in all cases (under CT-guidance in central and deep lesion- 43 cases; USG guidance in lesions close to chest wall- 17 cases; with the help of chest X'ray- 9 cases). FNA were done by spinal 25 gauze sterile needle, attached with $10 \mathrm{~mL}$ sterile syringe. Smears were fixed by 95\%ethyl alcohol and stained according to Papanicolaou's stain. Bronchoscopy was possible in 54 cases. Of the remaining cases, bronchoscopy was refused by 7 patients and 9 patients were not suitable for bronchoscopy. Out of 54 patients, biopsy was taken in 43 cases, where endobronchial lesions were seen. Slide was prepared and hematoxillin and eosin stain were done. Brush was taken from 42 patients. Smears preparation and fixation and staining were done similar to those of FNAC.

Cytobrushing were done in 42 cases. Of them, biopsy was possible in 34 cases only (Table I).

No lesion was seen in 11 patients by bronchoscope. Lesions were seen in 43 cases from where biopsy was taken for histopathological examination Table II). The statistical evaluation of the findings of FNAC and brush are shown in Table III.

Complications were minimum in this study. In FNAC, 6 (8.57\%) patients developed small pneumothorax, which disappeared spontaneously. Mild hemoptysis occurredin 3 patients (4.29\%), which were transient and required no treatment. In cases of brush with biopsy, 5 (11.19\%) patients developed hemoptysis, which were self-limited.

As the incidence of bronchogenic carcinoma continues to rise, there is increased need to establish diagnostic protocols that are simple, rapid and reliable. Among these, the cytologic evaluation of bronchial brushings and FNA samples has become widely established. However, the relative value of these two modalities remains the subject of debate. This study was aimed to find out the efficacy of transthoracic FNA and bronchial brush cytology in 
the diagnosis of bronchogenic carcinoma with their cyto-morphological pattern and to analyze the relative values of them in comparison to bronchoscopic biopsy, taken as the final standard.

The high rate of sensitivity and negative predictive value were due to small number of cases in this study group. Similar finding (sensitivity 100\%) was found in the study of Jain et al $(1997)^{7}$ in which the sample size was 45 .

There was one false positive case in FNAC in this study. But brush biopsy report was found similar to FNAC report in that case. Possibly the brochoscopic biopsy failed to sample the lesion. Similar cases were seen in the study of Cagle et al

Table I: Morphological correlation of brush cytology and histopathological diagnosis

\begin{tabular}{|c|c|c|c|c|c|c|c|c|}
\hline \multirow{2}{*}{$\begin{array}{l}\text { Cytopathological } \\
\text { diagnosis by } \\
\text { brush (No.) }\end{array}$} & \multicolumn{8}{|c|}{ Histopathological diagnosis } \\
\hline & $\begin{array}{l}\text { Squamous cell } \\
\text { carcinoma }\end{array}$ & $\begin{array}{l}\text { Adenocar- } \\
\text { cinoma }\end{array}$ & $\begin{array}{l}\text { Small cell } \\
\text { carcinoma }\end{array}$ & $\begin{array}{l}\text { Large cell } \\
\text { carcinoma }\end{array}$ & $\begin{array}{l}\text { Poorly different- } \\
\text { tiated carcinoma }\end{array}$ & Suspicious & Benign & Total \\
\hline $\begin{array}{l}\text { Squamous cell } \\
\text { ca.rcinoma (22) }\end{array}$ & 21 & & & & & & 1 & 22 \\
\hline $\begin{array}{l}\text { Adenocarcinoma } \\
\text { (5) }\end{array}$ & & 5 & & & & & & 5 \\
\hline $\begin{array}{l}\text { Small cell } \\
\text { carcinoma (1) }\end{array}$ & & & 1 & & & & & 1 \\
\hline $\begin{array}{l}\text { Large cell } \\
\text { carcinoma (1) }\end{array}$ & & & & 1 & & & & \\
\hline $\begin{array}{l}\text { Poorly } \\
\text { differentiated } \\
\text { carcinoma (0) }\end{array}$ & & & & & & & & \\
\hline Suspicious (2) & 1 & & & & 1 & & & 2 \\
\hline Benign (3) & & & & & & & 3 & 3 \\
\hline Total (34) & 22 & 5 & 1 & 1 & 1 & & 4 & 34 \\
\hline
\end{tabular}

Table II: Morphological correlation of FNAC and histopathological diagnosis

\begin{tabular}{|c|c|c|c|c|c|c|c|c|}
\hline \multirow{2}{*}{$\begin{array}{l}\text { Cytopathological diagnosis } \\
\text { by FNAC (No.) }\end{array}$} & \multicolumn{8}{|c|}{ Histopathological diagnosis } \\
\hline & $\begin{array}{l}\text { Squamous cell } \\
\text { carcinoma }\end{array}$ & $\begin{array}{l}\text { Adenocar- } \\
\text { cinoma }\end{array}$ & $\begin{array}{l}\text { Small cell } \\
\text { Carcinoma }\end{array}$ & $\begin{array}{l}\text { Large cell } \\
\text { carcinoma }\end{array}$ & $\begin{array}{l}\text { Poorly diff. } \\
\text { carcinoma }\end{array}$ & Suspicious & Benign & Total \\
\hline $\begin{array}{l}\text { Squamous cell carcinoma } \\
\text { (29) }\end{array}$ & 28 & 0 & 1 & 0 & 0 & 0 & & 29 \\
\hline Adenocarcinoma (7) & 1 & 5 & 0 & 0 & 0 & 0 & 1 & 7 \\
\hline Small cell carcinoma (1) & 0 & 0 & 1 & 0 & 0 & 0 & & 1 \\
\hline Large cell carcinoma (2) & 0 & 0 & 0 & 2 & 0 & 0 & & 2 \\
\hline Poorly diff. carcinoma (1) & 0 & 0 & 0 & 0 & 1 & 0 & & 1 \\
\hline Suspicious (1) & 1 & 0 & 0 & 0 & 0 & 0 & & 1 \\
\hline Benign (2) & 0 & 0 & 0 & 0 & 0 & 0 & 2 & 2 \\
\hline Total (43) & 30 & 5 & 2 & 2 & 1 & 0 & 3 & 43 \\
\hline
\end{tabular}

Table III: Statistical evaluation of transthoracic FNAC and brush in the series

\begin{tabular}{llllll}
\hline Method & Sensitivity Specificity & \multicolumn{2}{c}{ Predictive value } & \multirow{2}{*}{ Accuracy } \\
\cline { 3 - 4 } & & & Positive & Negative & \\
\hline FNAC & $100 \%$ & $66.6 \%$ & $97.50 \%$ & $100 \%$ & $92.86 \%$ \\
Brush & $100 \%$ & $75 \%$ & $96.55 \%$ & $100 \%$ & $87.50 \%$ \\
\hline
\end{tabular}

$(1995)^{8}$. They showed 11 cases, where FNACs were positive for malignancy but the biopsies failed to sample the lesion. In the present study, the specificity of FNAC was lower than that of many other studies. The presence of 1 unwanted false positive case and fewer numbers of true negative cases made the specificity lower. 
In this study, 7 (10\% of the total cases) cases positive for malignancy in FNAC, were negative in bronchoscopy. The lesions were beyond the reach of bronchoscope. However brush biopsy was taken in 5 cases and all were found malignant. These cases were not included in statistical evaluation due to lack of histopathological confirmation. Clinically, they were malignant and treated accordingly. Similar findings were also seen in the series of Rahman et al (2000) ${ }^{2}$, Ahmad (1998) ${ }^{9}$, in which most of the peripheral lung lesions were found bronchoscopically negative, though they were definitely diagnosed as malignant by FNAC or/and by brush biopsy.

Complications were minimum both in FNAC and brush in the present study. These findings were closed to those of Walace et al $(2000)^{6}$, Quiyyum et al $(2000)^{10}$.

In conclusion, both the cytological processes i.e. transthoracic FNAC and cytobrushing are the effective, safe and reliable methods in the diagnosis of bronchogenic carcinoma.

Md. Quamrul Hassan, M. Shahab Uddin Ahamad, Syed Ahmed and M. A. Wahhab Chowdhury

Department of Pathology, Chittagong Medical College, Chittagong, Bangladesh.

DOI: 10.3329/bmrcb.v36i1.4215

\section{References}

1. Kawaraya M, Gemba K, Ueoka H, Nishil K, Kiura K, Kodani T, Tabata M, Shibamyane T, Kitajima T, Tanimoto M. Evaluation of various cytological examinations by bronchoscopy in the diagnosis of peripheral lung cancer. BJC. 2003; 89: 1885-88.

2. Rahman MM, Hossain MA, Hassan MR, Bhuiyan MSS, Ahmad MM. Importance of bronchial biopsy, brushing, and BAL as diagnostic modalities in respiratory medicine. Chest Heart J. 2000; 24: 47-51.

3. Seaton D. Diagnostic procedure. In: Crofton \& Douglas's Respiratory diseases. $5^{\text {th }}$ ed. Edinburgh, Blackwell Science Ltd, 2000, pp 148-92.

4. Rosai J. Carcinoma respiratory tract. In: Juan Rosai \& Ackerman's Surgical pathology. $9^{\text {th }}$ ed. Edinburgh, Mosby, 2004, pp 387-458.

5. Suen KC. Introduction and general considerations. Atlas \& text of aspiration biopsy cytology. Baltimore, Willium \& Wilkins, 1990, pp 1-14.

6. Wallace MJ, Krishnamurthy S, Broemeling LD, Gupta S, Ahrar K, Morello FA, Hicks ME. CT-guided percutaneous fine needle aspiration biopsy of small $(1 \mathrm{~cm}$ or less) pulmonary lesions. Radiology 2002; 225: 82328.

7. Jain SK, Agrawal RI, Devi M, Singh M, Agrawal M, Jain S, Dui M, Singh M, Kumar D, Tani S. False results in fine needle aspiration cytology of intrathoracic masses. Lung India 1997; 15: 17-19.

8. Cagle PT, Kovach M, Ramzy I. Causes of false results in transthoracic fine needle lung aspirates. Actacytol 1995; 37: 16-20.

9. Ahmad MM. Comparison between fine needle aspiration cytology (FNAC) and fiber-optic bronchoscopy (FOB) in the diagnosis of peripheral pulmonary lesions. [MD Thesis]. Institute of Diseases of Chest and Hospital, Dhaka, 1998, pp 84-117.

10. Quiyyum MA, Hiron MM, Islam MS, Rouf MA, Rahman SMS, Jahan R, Rowshan J, Hassan MR, Rahman MM. Role of bronchial brushing and bronchial biopsy in the diagnosis of lung cancer. Chest Heart J. 2002; 26: 54-61.

\section{Angiographic profile in patients with congenital anomalous origin of the coronary arteries}

Coronary artery anomaly occurs in less than $1 \%$ of the general population. It is frequently found in association with other major congenital cardiac defects. This letter focuses on isolated coronary artery anomalies (i.e., in the absence of other major congenital cardiac defects). In adults, the clinical interest in coronary anomalies relates to their occasional association with sudden death, myocardial ischemia, congestive heart failure, or endocarditic. In addition, presence of coronary artery anomalies may, at times, create challenges during coronary angiography, percutaneous coronary interventions and coronary artery bypass surgery ${ }^{1-4}$. Accordingly this study was done to evaluate the anatomical patterns, frequency of occurrence and significance of coronary artery anomalies in patients studied angiographically for proper management of the patients.

This study included 4,000 patients who underwent coronary angiography from 2004 to 2007 in a single center. Clinical histories, physical examinations, noninvasive laboratory studies, catheterization data and follow-up surveys were obtained. Patients with coronary anomalies occurring as part of congenital complex heart disease were excluded in this study. Patients with isolated coronary artery anomalies were included in the study. Anatomically, patients were classified into two groups: those with anomalies of origin and distribution and those with coronary artery fistulae. Clinically anomalies may be arbitrarily divided into benign and potentially dangerous. 